"gradients" were published for twenty-four stars "suitable for use as spectrophotometric standards", and these intercomparisons were of such quality that they scarcely had to be modified at all as a result of the main programme which followed. This comprised 250 stars, most of them fainter than the standard ones; but the foundations had now been laid, and the advent of the new 36 -in. Yapp reflector in 1934 also speeded the work. By 1938, when Greaves was appointed to Edinburgh, there was little still to do except publish the extensive results.

An essential part of photographic spectrophotometry is the calibration of the plates, and since it would have been very time-consuming to use, in this, the long exposures which had to be used on stars, the question of 'reciprocity failure' had had to be faced. Greaves reduced this somewhat venerable bogey to very manageable proportions, and definitely cstablished the value of photography as a precise quantitative tool, at a time when photocells were still too insensitive to compete in this field.

The Second World War came soon after his move to Edinburgh, and for a while his principal concern was with the time service, where he co-operated closely with the Greenwich station that had been evacuated to Abinger; a substantial share of the advance in accuracy which occurred about this time, in spite of difficult conditions, was due to him. After the War, he obtained for his Observatory a badly needed increase in staff, and spectrophotometric data both on the Sun and on early-type stars have come increasingly from Edinburgh in recent years. Fxtensive work is in progress that would undoubtedly have benefited further from his leadership if he had lived.

Greaves definitely enjoyed taking charge of things, and could keep a committee firmly to the point. He served for six years as secretary of the Royal Astronomical Society, and was president during 1947-49. He was an active member of several commissions of the International Astronomical Union, serving for seven years as president of the one for photometry. His influence in the British National Committee for Astronomy was considerable, and he was one of the keenest sponsors of the plan for a large paraboloid at Jodrell Bank.

He will be warmly remembered by those who have worked under him, and with him. His complete integrity, and his devotion to astronomy, were unquestionable; but his numerous generosities may often have been less commonly known. The proportion of his papers which bear also the names of one or more subordinates is high, and this reflects not only his scrupulous fairness but also his power of stimulating the best efforts of his staff in the first place. He was capable of brusqueness, and even more, on occasion; but those who could see past this will remember the very real tact and skill with which he would guide and help all, whether old subordinates or new colleagues, who were associated with him.

R. D'E. Atkinson

\section{Dr. F. H. Burstall}

Dr. F. H. Burstali, who died on December 2 at the untimely age of fifty-two, had spent the whole of his working life at Teddington. He was one of a small band who were recruited by the late Sir Gilbert Morgan to staff the Chemical Research Laboratory (of the Department of Scientific and Industrial Research) when it was founded in 1925 ; and it can be said with truth that no one has done more to establish the prestige and repute that the Laboratory has, in the meantime, achieved.

The second son of the late Prof. F. W. Burstall (who held the chair of mechanical enginooring and was dean of the Faculty of Science in the University of Birmingham), Francis Burstall did not follow the profession in which other members of his family have achieved distinction. After graduating at Birmingham with first-class honours in chemistry, he became research assistant to Morgan, who had been his professor and was about to tako up a new appointment as superintendent of the Teddington Laboratory.

As a young man Burstall was entirely unsparing of the time and effort he applied to chemical research. He made substantial contributions to the organic chemistry of selenium and tellurium, undeterred by the frequently obnoxious nature of the materials he had to handle. It was, however, by his work on metallic co-ordination compounds that ho won recognition as an authority in a field then little cultivated. In a book published in 1933, of which he was co-author with Morgan, he provided an admirable survey of the more recent developments in this branch of inorganic chemistry.

When war came in 1939 , Burstall was obliged to take on a succession of problems which, important though they were at the time, offered little of continuing interest, and it was only with the ending of hostilities that his Department was able to make the best use of his very versatile ability. In 1947 he was placed in charge of a small section set up to study the analysis of uranium and thorium ores on behalf of the Department of Atomic Energy. The extraordinary value of the contribution that he and the staff he led (and inspired with some of his own enthusiasm) were able to make to the national effort in this new field was quickly recognized. Greater responsibilities were laid upon Burstall, and his unit ultimately became so large that an extensive new building was constructed and equipped to accommodate what now became tho Radiochemical Group of the Chemical Research Laboratory. Those who knew what Burstall put into his task will always see in this fine laboratory a memorial to his success in what, unfortunately, was to be the last phase of his scientific career. Much must remain untold; nevertheless, the series of papers in which he and his colleagues revealed their application of chromatography to the separation of metals indicate the power and generality of a technique they were among the first to use. The formal seal was set on Burstall's accomplishments in chemical research when in 1952 he attained the academic distinction of D.Sc. of the University of London.

Modest and self-effacing, Burstall was nevertheless a man whose judgments were shrewd, being based on wide (if unparaded) knowledge and deep self-communion. He had an extraordinary charm for his friends and colleagues. This was due to the utter impossibility for him to do or say anything in the slightest degree unkind or inconsiderate. His main preoccupation throughout his life was with chemistry, which to him was far more than the means to a livelihood. 'To purely personal advancement he nover gave a thought ; nevertheless, he found a high degree of self-fulfilment as a scientist in the service to which he gave his loyalty and whose traditions he upheld.

In the course of his last illness he underwent two major operations and it almost seemed after the first that hope could be entertained of a recovery. Un- 
fortunately this was not to be. Dr. Burstall bore his grievous afflictions with stoicism for more than twelve months. He is survived by his wife, whom he married in 1929 , and two sons.

E. A. Coulson

Prof. G. T. R. Hill

Prof. G. T. R. HrLL, who died recently at his home in Ireland, was a member of a very distinguished family. His father, the late Dr. M. J. M. Hill, was professor of mathematics and a vicechancellor of the University of London. His elder brother, the late Air Chief Marshal Sir Roderic Hill, became rector of the Imperial College of Science and Technology and also vice-chancellor of the University of London, and his sister, Dr. Gwen Hilton, is now director of the Radiotherapy Department of University College Hospital.

The two brothers both had close interests in aeronautical engineering, and though their careers were quite different, one was very much complementary to the other in its contribution in this sphere to progress during the past thirty years.

Even as a boy, Geoffrey Hill's future career was unmistakably marked out. He spent much of his spare time making aircraft models, and at the age of seventeen secured a place for one of them at the Children's Exhibition at Olympia. He was educated at University College School and afterwards at University College, London, where as an engineering student he graduated in 1914. After a period of active service in the Royal Flying Corps at the beginning of the First World War, when he rose to the rank of captain and was awarded the Military Cross, he undertook responsibilities in aeronautical research for the Air Ministry. After demobilization in 1919 he pursued his absorbing interest in aeronautics as an experimental engineer and chief test pilot to Messrs. Handley Page, Ltd. By this time he had acquired a background of knowledge and experience which, coupled with his inventive ability, enabled him, in collaboration with his brother, to conceive the idea of the tail-less aircraft or Pterodactyl as it was afterwards called.

In 1922 Hill was awarded an 1851 Exhibition Senior Studentship, and after two years of research to test the validity of the principles that the two brothers had enunciated, he began the design and construction of a Pterodactyl. The work was supported in its early stages by the Aeronautical Research Committee and eventually the machine was further developed in association with the Westland Aircraft Co. when he joined that firm in 1926. It was shown to the public for the first time at the R.A.F. pageant at Hendon and is now in the Science Museum at South Kensington, where it bears witness to the great contribution which the two brothers made to aeronautical science by establishing the important principles demonstrated in this machine. The industry to-day owes them a deep debt of gratitude.

In 1934 Geoffrey Hill returned to his old College as Kennedy professor of engineering, and he held that post with great distinction until 1947, when he resigned to re-enter the aircraft industry as consultant to Short Brothers and Harland, Ltd., of Belfast. During the Second World War he was seconded to the Air Ministry and later the Ministry of Aircraft Production for research work, and as a pioneer in the invention of the isoclinic wing he made valuable contributions in helping to maintain the superiority of the Allies in the air. He was elected to fellowship of the Royal Aeronautical Society, and was awarded the D.Sc. in engineering of the University of London.

His most delightful personality and his charm of manner will always be treasured by the wide circle of his friends and acquaintances. His death at the early age of sixty is a great loss, not only as a personal one, but also to the science of aeronautical engineering.

H. M. BARLOW

\section{NEWS and VIEWS}

Wellcome Museum of Medical Science :

Lieut.-Colonel C. A. Bozman, O.B.E.

LieUt.-Coloned C. A. BozMan has been appointed director of the Wellcome Museum of Medical Science, and will take up his duties on February 1. Colonel Bozman, who received his medical training at the University of Edinburgh, joined the Indian Medical Service in 1924. He held various public health and laboratory appointments, including that of director of public health, Burma, and became a public health commissioner to the Government of India. After his retirement in 1947 he was successively lecturer in public health in the University of St. Andrews, health counsellor at the British Middle East Office, Cairo, and professor of preventive medicine at the University College of East Africa (Makerere College). His new post with the Wellcome Foundation will ensble Colonel Bozman to apply his wide knowledge of tropical medicine and pathology in the service of a Museum which has specialized in this field.

\section{Glasshouse Crops Research Institute :}

Dr. W. F. Bewley, C.B.E.

Dr. William F. Bewher retires from the post of director of the Glasshouse Crops Research Institute next summer. Bewley was educated at the University of Durham and first joined the staff of Rothamsted Experimental Station, being seconded for service in the Royal Field Artillery during the First World War. While at Rothamsted he collaborated with the late Dr. H. B. Hutchinson on the classic researches on partial sterilization of soil which were later to prove the salvation of the tomato industry. In 1919 he went to the research station in the Lea Valley founded in 1914 by the glasshouse growers of the district and later to become world-famous under his leadership as the Cheshunt Experimental and Research Station. He became director in 1921, and instituted the long series of experiments on glasshouse crops which laid the foundations of modern techniques. His many years of experience, first as a mycologist and later as an authority on all aspects of glasshouse cultivation, were summed up in his two standard books, "The Diseases of Glasshouse Crops" and "Commercial Glasshouse Crops". In 1954, the old Cheshunt Station became the new Glasshouse Crops Research Institute, with Bewley as director, and in 1955 its staff moved to the new site at Toddington near Littlehampton. Bewley's warm, friendly nature, together with his exceptional powers 